\title{
Tempos de imponderável revolução
}

\section{Claudio Coração}

\section{Resumo:}

Resenha do livro Como a geração sexo, drogas e rock n'roll salvou Hollywood.

\section{Palavras Chave:}

Cinema, geração, revolução, Nova Hollywood, Peter Biskind.

\begin{abstract}
:
Book review Como a geração sexo, drogas e rock n'roll salvou Hollywood.
\end{abstract}

\section{Keywords:}

Cinema, generation, revolution, New Hollywood, Peter Biskind.

BISKIND, Peter. Como a geração sexo, drogas e rock n'roll salvou Hollywood. Trad. Ana Maria Bahiana. Rio de Janeiro: Intrínseca, 2009.

O cinema narrativo clássico norte-americano sucessivamente trabalhou com as reproduções inerentes à sua fabricação, calcada na absorção da América como mito, e relacionada a uma indústria cultural vultosa. Se D. W. Griffith propusera (ou fabricara) um estatuto da condição narrativa audiovisual (de matriz literária realista), a consolidação dos gêneros audiovisuais cinematográficos nas décadas seguintes a 1920 (com intensa interferência do expressionismo e do surrealismo artísticos, no início) corroborou a sedimentação do cinema como dispositivo fundamental (ficcional) para a apreensão do mundo. Esse modelo entra em crise nos anos 1960, crise esta que imprime o anacronismo em relação aos westerns e melodramas "realistas" mais pomposos.

O crítico Peter Biskind, em Como a geração sexo, drogas e rock'n roll salvou Hollywood (Easy riders Raging bulls) localiza a etapa de transição da crise financeira dos estúdios de cinema para um novo tempo regido na contracultura. Nesse diapasão, segue o cinema dos Estados Unidos como a manifestação crítica metalingüística do próprio veículo, gerando outros aportes que não a doce representação da conquista do oeste ou dos arroubos do cotidiano do americano médio (em comédias de costumes, por exemplo). Nesse sentido, o american way of life é reinterpretado por uma "horda" de bárbaros dispostos a enfrentar o leão da crise dos estúdios e propor, à luz da cultura hippie flower power e das experiências lisérgicas, uma espécie de modelo narrativo - ainda clássico aos moldes de Kazan, Hawks e Ford - agora embutido pela lógica próxima da temática dos novos tempos (guerra do Vietnã, o desconforto da guerra 
fria, a desestruturação do modelo familiar, a incorporação e participação de novos atores no caldo social etc.). Esse momento é entendido por Biskind como a edificação de uma Nova Hollywood, balizada com os fundamentos dos gêneros a partir de jovens intelectuais diretores, produtores, atores e roteiristas que se emaranham no modus operandi de uma indústria de entretenimento condicionada, sobremaneira, a novos códigos de conduta, com os seguintes protagonistas: Peter Bogdanovich, Francis Ford Coppola, Dennis Hopper, Hal Ashby, Willian Friedkin, Robert Altman, Martin Scorsese, Steven Spielberg, George Lucas, Paul Schrader, Brian de Palma, Jack Nicholson, Robert de Niro, Dustin Hoffman, Al Pacino, Gene Hackman, Harvey Keitel, Jane Fonda, Diane Keaton, Faye Dunaway etc.

Nasce, pois, uma geração que subverte a lógica de Hollywood pelas funções internas do modo de apropriação clássico, mas respira - e isso Biskind ressalta sempre - os ares da modernidade cinematográfica européia e asiática a partir dos anos 1940. Ou seja, os "cinemas novos" de várias nacionalidades também são elementos fortes na apreensão/produção desse cinema, de certa forma, escapista e ditado pelos sintomas de um hedonismo genial. Nesse quesito, destacam-se, na descrição de Biskind, as circunstâncias vividas e regidas pelo dândi Peter Bogdanovich (Na mira da morte [1968], A última sessão de cinema [1971], Essa pequena é uma parada [1972], Lua de papel [1974]), o histriônico Willian Friedkin (Operação França [1971], O Exorcista [1973], O comboio do medo [1977]), o megalomaníaco Francis Ford Coppola (O poderoso chefão [1972], A conversação [1974], O poderoso chefão - parte II [1974], Apocalipse now [1979]) e o ególatra Warren Beatty (O céu pode esperar [1978], Reds [1981]).

A partir de uma série infindável de depoimentos dos protagonistas dessa epopéia de criação artística, Biskind desvenda os meandros da produção cinematográfica recente pela lógica solidificada da comunicação de massa, a conviver com seus códigos de conduta de frivolidade, celebração e exageros (próximos do rock n'roll). Não à toa, Biskind elucida sua análise jornalística e coloquial, a cada intertítulo, percorrendo os principais aspectos do fenômeno "novo", apropriando-se de nomes de canções e álbuns dos Rolling Stones, por exemplo, (Exile on main street, Sympathy for the devil ).

A narrativa de Biskind em seu percurso é emblemática na matriz da redenção - algo cristão próxima aos filmes de Scorsese, mas também pensada (segundo o autor) como um fragmento audiovisual cênico aos moldes de um Robert Altman ( $M * A * S * H$ [1970], Quando os homens são homens [1971], Nashville [1975]). Assim, existe uma demarcação temporal que se estende de Easy rider (1969) a Touro indomável (1980), num recorte que evidencia quão forte foi o processo de entrega de uma geração no future que "salvou" Hollywood da desgraça da representação colonialistalescravista de cunho expansionista. Mas este caminho - ressalta o crítico - é feito de/com ar de fogo e paixão, com mazelas (pessoais e profissionais) escancaradas durante o périplo.

Portanto, o jornalista antecipa o momento anterior à revolução que foi Easy rider quando diagnostica Bonnie e Clyde como um marco do libelo anti-western, mas desenhado numa chave estranha de filme noir , disposto a rivalizar com os códigos de uma modernidade que se instaurara. Esse estranhamento no embate discursivo é a grande chave para se estabelecer Bonnie e Clyde como marco preinaugural de um fenômeno. A apropriação desmedida insinuará nos bastidores da indústria cinematográfica norte-americana a eterna briga de egos (Warren Beatty versus o quase veterano Arthur Penn, os "quebra-paus generalizados entre Peter Fonda e Dennis Hopper). Portanto, é importante avisar, as mulheres surgem aqui e ali, na narrativa de Biskind, como demarcadoras éticas de um mundo permeado pela testosterona masculina: a personagem de Diane Keaton em $O$ poderoso Chefão - parte II ou a de Julie Christie em Quando os homens são homens parecem ser síntese de uma contraposição ao desajuste evidenciado por ex-combatentes do Vietnã, desgarrados urbanos de toda ordem, mafiosos incontestes e suburbanos, cowboys melancólicos etc. Easy rider (de predominância perspectívica masculina) é o grande emblema inicial da revolução porque nele se encontram as pistas dos desajustes de uma nova geração que se mostra essencialmente livre e perdida.

O mito da juventude é o grande estofo do período ao qual Biskind fotografa. Esse parece ser o libelo salvacionista que preconiza. Assim, os empreendimentos fincados por Coppola, Spielberg e Lucas (estes dois últimos vistos como nerds empreendedores) são peças-chaves para entendermos os rumos do 
cinema evento e termos em contraste a participação fragmentada e acelerada da narrativa visual norteamericana - quase sempre, de forma apressada - vista como um cinema fútil. Esse talvez seja o grande paradoxo do livro, isto é, como uma geração de grandes nomes intelectuais se "rende" ao jogo de uma indústria caracterizada pelo blockbuster. Há, no livro, vários pontos que parecem sintetizar essa perspectiva entre um cinema construído e pensado na autoria e outro, ensejado na indústria de espetáculos mais impactante. Tubarão [1975] e Star wars [1977] são os grandes símbolos de um lado, enquanto A última sessão de cinema [1971] é um paradigma de outro. O espectador de cinema, nos anos 1970, depara-se, no entanto, com obras-primas que fazem do prazer cinematográfico da fruição registro de um estado de decomposição intelectual propositalmente incômodo, reforçando desajustes e preconizando tempos sombrios e decadentistas (antecipando a produção dos irmãos Coen e de Quentin Tarantino, tempos depois). É nessa pista que se entende a saga de $O$ poderoso chefão e Taxi driver (1976), dois referenciais pessimistas nas relações da jornada sígnica da América como terra de oportunidade, em que o cenário urbano se desmonta ante o caos da violência sem lastro.

Tais filmes são tão representativos que experiências "menores" de Hal Ashby (Amargo regresso [1978]) e Paul Schrader, o grande roteirista da geração (Gigolô americano [1980]), são colocadas à margem do processo. Aqui, cabe ressaltar a autoria como entendimento do cinema naquele período. Easy rider inaugura de certa forma a autoria baseada em códigos de fundamentação moderna cinematográfica que segundo Buscombe, no ensaio Ideias de autoria, estaria na produção de novos conhecimentos (BUSCOMBE, 2004). Inácio Araujo, em recente ensaio ( $O$ autor! $O$ autor! ), pontua os aspectos da autoria no viés do momento de uma nova definição do que seja cinema.

É interessante ressaltar que Biskind reitera os aspectos reconstruídos pela Nova Hollywood no discurso do cinismo e da ironia a partir do noir (Chinatown [1975]), do terror de culpa (O exorcista), da ação rivalizante urbana de Operação França e do lirismo clássico de Lua de papel etc. Nessa reconstrução de gêneros, Tubarão surge como força porque revela outra condição do suspense como dispositivo: a espera de algo que nunca chega, reforçando o caráter de um filme de formação, apropriado de muitas teorias do cinema de autor (Bogdanovich, por exemplo, era um perfeccionista estudioso da questão das linhagens cinematográficas do cinema americano e europeu).

Nos estertores do fim de década de 70, Biskind elucida Apocalipse Now (em seu turbilhão de conflitos internos na produção) e Touro Indomável, de Martins Scorsese, como exemplares incontestes de um tempo que parecia se findar. A canção de Bob Dylan My back pages serve como trilha de um tempo quase enterrado pelo forte consumo de drogas (a cocaína entra numa etapa evidenciada por indicadores de competitividade capitalista cada vez mais radical). Portanto, a crise do personagem Jake La Motta (em Touro indomável ) e a busca do tenente Willard ao Coronel Kurtz (em Apocalipse now ) advertem sobre um tempo que se desapega de seus propósitos iniciais, lá atrás. A certa altura os autores do marco inaugural Easy rider (Fonda, Hopper) estavam "em outra estratosfera drogadiça”, fora do jogo evidenciado por seres apolíneos como George Lucas e Steven Spielberg, no tempo e no cenário yuppie que se avizinhava. O purgatório de todos eles, sorrateiramente, foi constituído pelos anos 1980, compostos por uma geração herdeira de seus discursos (principalmente a premissa da violência descontrolada): John Mc Tiernan, John Landis (esse, um midas da comédia), James Cameron etc. Mas já estamos em outra era, mais cínica e veloz, para a qual os fundamentos da contemplação (como no personagem Harry, de Gene Hackman, em A conversação ) ficariam mais distantes.

A geração que "salvou" Hollywood da crise de idéias e do conservadorismo foi a mesma geração que, paradoxalmente, referendou o novo estado de coisas (associação da violência ao discurso belicoso de Reagan). Entretanto, ver Scorsese e Coppola com seus sucessos atuais pode se insinuar que o tombo não foi tão grande. Mas, também, poderíamos perguntar (e Biskind o faz a todo o instante em Como a geração sexo, drogas e rock n'roll salvou Hollywood ): por onde anda Peter Bogdanovich? O que faz Paul Schrader? Qual o próximo filme de Willian Friedkin? Qual a nova viagem de Terence Malick? Viraram fantasmas na selva de grana da indústria cinematográfica (ou do cinema pretensamente independente), restando a eles metamorfosear-se na fala de Coronel Kurtz (imortalizado por Marlon Brando) ao diagnosticar o cinema contemporâneo industrial: "O horror, o horror". 


\section{Bibliografia:}

BUSCOMBE, Edward. "Ideias de autoria”. In: RAMOS, Fernão Pessoa (org.). Teoria contemporânea do cinema. Volume 1. São Paulo: Senac, 2004.

\section{Mini Currículo :}

Doutorando em comunicação pela ECA-USP, mestre em comunicação pela Unesp, jornalista e professor da Unip (Bauru) e FIB. 